\title{
KONTAMINASI TELUR SOIL TRASMITTED HELMINTH PADA SAYUR KANGKUNG (Ipomoea Aquatica) DI PASAR TRADISIONAL WILAYAH KOTAWARINGIN BARAT
}

\author{
${ }^{1}$ Miftachul Sobirin \\ ${ }^{1}$ STIKes Borneo Cendekia Medika Pangkalan Bun \\ ${ }^{1}$ Email : miftachul_sob@yahoo.co.id
}

\begin{abstract}
Abstrak
Infeksi cacing merupakan salah satu penyakit yang paling umum tersebar di seluruh dunia. Sampai saat ini penyakit kecacingan masih tetap merupakan suatu masalah kesehatan. Pada umumnya, cacing jarang menimbulkan penyakit serius tetapi dapat menyebabkan gangguan kesehatan kronis. Menurut Kementerian Kesehatan RI infeksi cacing dapat menimbulkan kerugian zat gizi berupa kalori dan protein serta kehilangan darah. Penelitian ini bertujuan untuk mengetahui adanya kontaminasi telur Soil Trasmitted Helminth pada sayur kangkung (Ipomoea aquatica) di pasar tradisional wilayah Kotawaringin Barat dengan metode flotasi. Jenis penelitian ini adalah penelitian survei yang bersifat deskriptif kuantitatif yaitu untuk mengetahui hasil identifikasi jumlah dan jenis telur cacing pada sayuran Kangkung di wilayah Kotawaringin Barat. Metode identifikasi telur cacing STH dilakukan dengan teknik flotasi. Hasil pemeriksaan telur nematoda usus pada sayuran Kangkung menunjukkan sebanyak 4 sampel positif terdapat kontaminasi telur nematoda usus atau sebanyak 13,33\% dan sebanyak 26 sampel tidak ditemukan adanya kontaminasi telur nematoda usus atau sebanyak $86,67 \%$.
\end{abstract}

Kata Kunci : Telur Soil Trasmitted Helminth, nematoda, flotasi

SOIL TRASMITTED HELMINTH EGG CONTAMINATION IN KANGKUNG VEGETABLES (Ipomoea Aquatica) IN THE TRADITIONAL MARKET OF WEST KOTAWARINGIN REGION

\section{ABSTRACT}

Worm infection is one of the most common diseases spread throughout the world. Until now, helminthiasis is still a health problem. In general, worms rarely cause serious illness but can cause chronic health problems. According to the Indonesian Ministry of Health, worm infections can cause nutritional losses in the form of calories and protein and blood loss. This study aims to determine the contamination of Sointh Trasmitted Helminth eggs in water spinach (Ipomoea aquatica) in the traditional markets of the West Kotawaringin region by the flotation method. This type of research is a quantitative descriptive survey research that is to determine the 
results of identification of the number and type of worm eggs in Kangkung vegetables in the Kotawaringin Barat region. The method of identification of STH worm eggs is carried out by flotation techniques. The results of examination of intestinal nematode eggs in kale vegetables showed that as many as 4 positive samples contained intestinal nematode egg contamination or as many as $13.33 \%$ and as many as 26 samples found no intestinal nematode egg contamination or as much as $86.67 \%$.

Keywords: Trasmitted Helminth Soil Eggs, nematodes, flotation

\section{PENDAHULUAN}

Infeksi cacing merupakan salah satu penyakit yang paling umum tersebar di seluruh dunia. Sampai saat ini penyakit kecacingan masih tetap merupakan suatu masalah kesehatan. Pada umumnya, cacing jarang menimbulkan penyakit serius tetapi dapat menyebabkan gangguan kesehatan kronis (Zulkoni, 2011). Menurut Kementerian Kesehatan RI (2006) infeksi cacing dapat menimbulkan kerugian zat gizi berupa kalori dan protein serta kehilangan darah. Selain itu dapat menghambat perkembangan fisik dan produktifitas kerja, dapat menurunkan ketahanan tubuh sehingga mudah terkena penyakit lainnya.

Berdasarkan data dari World Health Organization (WHO), lebih dari 1,5 miliar orang atau $24 \%$ dari populasi dunia terinfeksi Soil Transmitted Helminths (STH). Infeksi tersebar luas di daerah tropis dan subtropis dengan jumlah terbesar terjadi di sub-sahara
Afrika, Amerika, Cina dan Asia Timur (WHO, 2013).

Di Indonesia angka kesakitan karena terinfeksi cacing usus atau perut cukup tinggi. Hal ini dikarenakan letak geografis Indonesia di daerah tropik yang mempunyai iklim yang panas akan tetapi lembab. Pada lingkungan yang memungkinkan cacing usus dapat berkembang biak dengan baik terutama oleh cacing yang ditularkan melalui tanah (Soil Transmitted Helminth) (Astuti, 2008).

Berdasarkan data Kemenkes RI (2012), di Indonesia salah satu masalah kesehatan yang masih sangat tinggi adalah cacingan yang ditularkan melalui tanah yakni dari 33 provinsi menunjukkan rata-rata prevalensi $31,8 \%$. Cacing yang ditularkan melalui tanah disebut Soil Transmitted Helminth. Soil Transmitted Helminth (STH) adalah kelompok cacing nematoda usus yang memerlukan tanah untuk proses pematangan sehingga terjadi perubahan dari stadium non- 
infektif menjadi stadium infektif. Pada umumnya telur cacing akan bertahan pada tanah lembab, tumbuh menjadi telur yang infektif dan siap untuk masuk ke dalam tubuh manusia yang merupakan hospes defenitifnya.

Salah satu jenis sayuran yang sering terkontaminasi oleh Soil Transmitted Helminths (STH) adalah kangkung yang merupakan jenis sayuran yang umumnya dimasak dalam kondisi setengah matang. Adanya usaha untuk meningkatkan kesuburan tanaman sayuran dengan menggunakan tinja manusia sebagai pupuk menyebabkan sayuran seperti kangkung menjadi sumber infeksi dari Ascaris lumbricoides. Sayur kangkung dapat terkontaminasi telur cacing bukan hanya melalui penggunaan pupuk dari tinja manusia, dapat juga melalui perantara penggunaan tanah dan air yang telah terinfeksi telur cacing (Irianto, 2013).

Helminthes (cacing) adalah parasit berupa hewan bersel banyak yang tubuhnya simetris kiri-kanan. Cacing yang penting bagi manusia dikelompokkan ke dalam dua filum, yaitu Filum Plathyhelminthes dan Filum Nemathelminthes. Platyhelminthes adalah cacing yang mempunyai bentuk pipih, tidak mempunyai sistem peredaran darah, tidak bersegmen, tidak berongga badan dan tanpa lubang dubur. Nemathelminthes berasal dari kata yunani "nematos" yang berarti benang dan "helminthes" yang berarti cacing bulat atau cacing benang (Irianto, 2013).

Nemathelminthes mempunyai kelas nematoda. Menurut habitatnya nematoda dibagi menjadi dua kelompok yaitu nematoda usus dan nematoda darah dan jaringan (Irianto, 2013). Kelas nematoda usus berdasarkan cara penyebarannya dapat dibagi menjadi kelompok nematoda usus yang tidak memerlukan tanah dalam hidupnya dan kelompok yang ditularkan melalui tanah (Soil Transmitted Helminth). Kelompok nematoda usus yang tidak memerlukan tanah dalam siklus hidupnya yaitu spesies Enterobius vermicuralis, Trichinella spiralis dan Capillaria philippinensis (Natadisatra, 2009).

(Soil Transmitted Helminth adalah cacing golongan nematoda yang memerlukan tanah untuk pematangan dari bentuk noninfektif menjadi bentuk infektif. Kelompok Soil Transmitted Helminth terdiri atas beberapa spesies 
yaitu Trichuris trichura, cacing tambang (Necator americanus dan Ancylostoma duodenale), Strongyloides stercolaris, Ascaris lumbricoides, dan beberapa spesies Trichostongylus (Natadisatra, 2009).

Infeksi STH ditemukan tersering di daerah iklim dan lembab yang memiliki sanitasi dan hygiene buruk. STH hidup di usus dan telurnya akan keluar melalui tinja hospes. Jika hospes defekasi di luar (taman, lapangan) atau jika tinja mengandung telur dibuahi maka telur akan tersimpan dalam tanah. Telur menjadi infeksius jika telur matang.

Telur berukuran 50x25 mikron, memiliki bentuk seperti tempayan, pada kutubnya terdapat operculum yaitu semacam penutup yang jernih dan menonjol. Dinding terdiri atas dua lapis, bagian dalam yang jernih dan bagian dalam yang berwarna kecoklatan (Natadisastra, 2009).

Seekor cacing betina dalam satu hari dapat bertelur 3000-4000 butir. Telur ini keluar bersama tinja, dan ditanah dengan suhu optimum dalam waktu 3-6 minggu menjadi infektif. Manusia terinfeksi dengan memakan telur infektif. Cacing ini berhabitat diusus besar (Safar, 2009) a. Telur cacing tambang (Necator americanus dan Ancylostoma duodenale), Strongyloides stercolaris

Telur mempunyai selapis kulit hialin yang tipis transparan. Telur yang segar baru keluar mengandung 2-8 sel. Bentuk telur Ancylostoma duodenale dan Necator amricanus sama, hanya berbeda dalam ukuran telur. Ancylostoma duodenale berukuran (56-60) $\quad$ x (36-40) $\mu$ sedangkan telur Necator americanus berukuran (64-76) $\mathrm{x}$ (36-40) $\mu$. Seekor betina Ancylostoma duodenale maksimum dapat bertelur 20.000 butir sedangkan Necator americanus 10.000 butir (Irianto, 2013).

\section{b. Telur Ascaris lumbricoides}

Seekor cacing Ascaris lumbricoides betina setiap harinya dapat menghasilkan 200 ribu telur. Telurnya berbentuk ovoid (bulat telur) dengan kulit tebal dan transparan terdiri dari membran lipoid yang relatif non-permabel (Irianto, 2009). Ada 4 bentuk telur cacing Ascaris lumbricoides yaitu telur fertil, telur decortikated, telur infertil dan telur berembrio. 
Telur Ascaris lumbricoides akan keluar bersama tinja manusia, masih belum bersegmen dan tidak menular. Di alam telur berada di tempat-tempat yang lembab, temperatur yang cocok, dan cukup sirkulasi udara. Telur tumbuh dengan baik sampai menjadi infektif setelah kira-kira 20-24 hari. Telur Ascaris lumbricoides tidak akan tumbuh dalam keadaan kering, karena dinding telur harus dalam keadaan lembab untuk pertukaran gas. Pertumbuhan telur Ascaris lumbricoides tidak tergantung dari $\mathrm{pH}$ tanah dan juga telur sangat resisten, maka kekurangan oksigen tidak menjadi sebab utama penghambat pertumbuhan telur. Pertumbuhan telur Ascaris lumbricoides dapat terjadi pada suhu 8-37oC (Irianto, 2009).

\section{METODA PENELITIAN}

\section{Alat}

Alat yang digunakan pada penelitian ini yaitu: pisau, object glass, cover glass, pipet tetes, tabung reaksi, pinset, beaker glass dan mikroskop.

\section{Bahan}

Bahan yang digunakan pada penelitian ini yaitu kangkung, $\mathrm{NaCl}$ $0,9 \%$, tissu, masker, handscoon.

\section{Rancangan Penelitian}

Jenis penelitian ini adalah penelitian survei yang bersifat deskriptif kuantitatif yaitu untuk mengetahui hasil identifikasi jumlah dan jenis telur cacing pada sayuran Kangkung di wilayah Kotawaringin Barat. Metode identifikasi telur cacing STH dilakukan dengan teknik flotasi.

\section{Variabel penelitian}

Variabel penelitian terdiri dari Variabel bebas (Independent) berupa sayuran Kangkung, sedangkan Variabel terikat (dependent) adalah adanya telur cacing nematoda usus.

\section{Teknik Sampling}

Sampel yang digunakan pada penelitin ini adalah sayuran Kangkung. Teknik pengambilan sampel yaitu random sampling yang diambil dari pedagang di pasar tradisional di wilayah Kotawaringin Barat yang menjual kangkung. Jumlah sampel yang diambil sebanyak 30 pedagang sayur yang menjual kangkung.

\section{Populasi dan Sampel}

Sampel yang digunakan pada penelitian ini yaitu sayuran Kangkung. Yang dijual di wilayah Kotawaringin Barat. Sejumlah sampel penelitian ini sebagai wakil populasi yang representatif. Sampel yang representif yang berada di wilayah Kotawaringin Barat ditentukan sebanyak 30 pedagang sayur yang menjual kangkung. 
Cara Kerja

1. Sampel kangkung yang diperoleh dari beberapa wilayah di Kotawaringin Barat dipotong menjadi bagian kecil-kecil.

2. Sebanyak 50 gram kangkung direndam dengan larutan $\mathrm{NaCL}$ $0,9 \% 200 \mathrm{~mL}$ dalam beaker glass $500 \mathrm{ml}$.

3. Setelah 30 menit, sayuran diaduk dengan pinset hingga merata, kemudian dikeluarkan sayuran.

4. Air rendaman dipindahkan dalam tabung reaksi

5. Diletakkan penutup kaca objek dengan hati-hati di atas mulut tabung. Pastikan penutup kaca objek bersentuhan dengan cairan, tanpa gelembung udara.

6. Didiamkan selama 15 menit.

7. Diangkat penutup kaca objek dengan hati-hati, setetes cairan harus tersisa pada penutup kaca objek tersebut.

8. Diletakkan penutup kaca objek pada sebuah kaca objek dan diamati dengan mikroskop segera dengan perbesaran $10 \times 10$.

\section{Analisis Data}

Data yang diperoleh selanjutnya dianalisis secara deskriptif kuantitatif dengan menghitung jumlah sampel yang positif mengandung telur nematoda usus dan yang negatif, kemudian dihitung spesies telur nematoda usus dan dihitung presentase telur nematoda usus yang ditemukan dari sampel yang diperiksa. Dalam mencari presentase dari kangkung yang positif dan negatif terkontaminasi telur cacing nematoda usus dapat digunakan rumus proporsi sebagai berikut:

$$
\mathrm{P}: F N x 100 \%
$$

Keterangan :

P : Persentase

$\mathrm{F}$ : Frekuensi

$\mathrm{N}$ : Jumlah

\section{HASIL DAN PEMBAHASAN}

Hasil pemeriksaan mikroskopis terhadap kangkung yang diperoleh dari pasar di wilayah Kotawaringin Barat diketahui bahwa pada beberapa sampel yang diperiksa tersebut ditemukan gambaran adanya kontaminasi telur nematoda usus. Setelah dilakukan pemeriksaan pada sampel kangkung dengan metode pemeriksaan flotasi, maka didapatkan hasil sebagai berikut:

\begin{tabular}{l|l|l} 
Sampel & Total & Hasil
\end{tabular}




\begin{tabular}{|l|l|l|l|}
\hline \multirow{2}{*}{ sampel } & \multicolumn{2}{|c|}{ pemeriksaan } \\
\cline { 3 - 4 } & & positif & Negatif \\
\hline Kangkung & 30 & 4 & 26 \\
\cline { 3 - 4 } & & $13,33 \%$ & $86,67 \%$ \\
\hline
\end{tabular}

Tabel 4.1 Hasil pemeriksaan telur STH pada kangkung

Hasil pemeriksaan telur nematoda usus pada sayuran Kangkung menunjukkan sebanyak 4 sampel positif terdapat kontaminasi telur nematoda usus atau sebanyak 13,33 \% dan sebanyak 26 sampel tidak ditemukan adanya kontaminasi telur nematoda usus atau sebanyak $86,67 \%$.

\section{B. Hasil pemeriksaan Jenis telur STH} yang terdapat pada kanglung

Hasil pemeriksaan telur nematoda usus yang ditemukan pada sayuran kangkung ditemukan telur dari spesies Ascaris lumbricoides dan Trichuris trichiura.

\begin{tabular}{|l|l|l|l|}
\hline \multirow{2}{*}{$\begin{array}{l}\text { Kode } \\
\text { sampel }\end{array}$} & \multicolumn{3}{|c|}{ Spesies telur STH } \\
\cline { 2 - 4 } & $\begin{array}{c}\text { A. } \\
\text { lumbricoides }\end{array}$ & $\begin{array}{c}\text { T. } \\
\text { trichiura }\end{array}$ & $\begin{array}{c}\text { Cacing } \\
\text { tambang }\end{array}$ \\
\hline T1 & - & - & - \\
\hline T2 & - & - & - \\
\hline T3 & - & - & - \\
\hline T4 & - & - & - \\
\hline T5 & + & - & - \\
\hline T6 & - & - & - \\
\hline T7 & - & - & - \\
\hline T8 & + & - & - \\
\hline T9 & - & - & - \\
\hline T10 & - & + & - \\
\hline
\end{tabular}

\begin{tabular}{|l|l|l|l|}
\hline T11 & - & - & - \\
\hline T12 & - & - & - \\
\hline T13 & - & - & - \\
\hline T14 & - & - & - \\
\hline T15 & - & - & - \\
\hline T16 & - & - & - \\
\hline T17 & - & - & - \\
\hline T18 & - & - & - \\
\hline T19 & + & - & - \\
\hline T20 & - & - & - \\
\hline T21 & - & - & - \\
\hline T22 & - & - & - \\
\hline T23 & - & - & - \\
\hline T24 & - & - & - \\
\hline T25 & - & - & - \\
\hline T26 & - & - & - \\
\hline T27 & - & - & - \\
\hline T28 & - & - & - \\
\hline T29 & - & - & - \\
\hline T30 & - & - & - \\
\hline
\end{tabular}

Hasil pemeriksaan spesies telur nematoda usus pada kangkung diketahui terdapat beberapa spesies telur nematoda usus. Spesies telur nematoda usus yang paling banyak ditetemukan adalah telur Ascaris lumbricoides. Pada 30 sampel kangkung ditemukan 3 telur dari spesies A.lumbricoides fertile dan infertil, serta 1 telur dari spesies Trichuris trichiura.

Penelitian ini dilakukan untuk mengetahui ada tidaknya telur cacing STH pada kangkung yang dijual di wilayah Kotawaringin Barat. Jumlah sampel penelitian ini sebanyak 30 sampel dengan teknik pengambilan sampel secara random sampling. Pasar- 
pasar yang dijadikan tempat pengambilan sampel sebagian besar terlihat layak, dinilai dari kondisi tempat cukup bersih dan penataan sayur yang cukup baik, tetapi sebagian kecil pasar masih terlihat kesan kumuh dan jorok. Kondisi ini dinilai dari tempat pasar yang tidak bersih dan penjual yang meletakkan sayuran di sembarang tempat, tidak memakai alas yang bersih.

Tempat penyimpanan sayuran yang tidak bersih dan lembab, memungkinkan telur STH untuk bertahan dan berkembang menjadi bentuk efektif. Selain itu juga bisa terjadi kontaminasi silang, baik dari telur yang tertinggal di tempat penyimpanan maupun dari sisa sayuran yang lama ke sayuran lain yang berpotensi mengandung telur STH. Penyimpanan sayuran dilemari pendingin dapat mempertahankan kesegaran dari sayuran, namun perlu diketahui bahwa pendinginan di lemari pendingin tidak dapat menghilangkan atau merusak telur cacing. Telur A.lumbricoides dapat bertahan pada suhu kurang dari $8^{\circ} \mathrm{C}$ walaupun pada suhu ini dapat merusak telur T.trichiura (Siskhawahy, 2010).
Jenis telur cacing yang ditemukan pada kangkung adalah telur dari spesies A.lumbricoides fertil dan nonfertil. Jenis telur cacing ini memang yang paling dominan mengkontaminasi sayuran kangkung dan kemangi. Bentuk infertil yang diperiksa merupakan bentuk infertil dari spesies telur A.lumbricoides. Bentuk infertil telur A.lumbricoides pada penelitian ini lebih disebabkan oleh sifat dari telur A.lumbricoides yang di dalam tanah tetap hidup pada suhu beku yang biasa terdapat pada musim dingin. Pada penelitian ini, ditemukan kontaminasi telur A.lumbricoides lebih besar daripada telur T.trichiura. Hal ini dikarenakan telur A.lumbricoides memiliki ketahanan yang lebih baik di lingkungan. Kontaminasi telur cacing dalam kangkung yang dijumpai pada penelitian ini harus diwaspadai karena merupakan salah satu sumber penularan penyakit kecacingan.

\section{KESIMPULAN}

Berdasarkan penelitian dapat disimpulkan bahwa terdapat kontaminasi telur cacing nematoda usus pada sayuran kangkung sebesar $13,33 \%$ yang dijual di pasar wilayah Kotawaringin Barat dan jenis telur cacing yang ditemukan pada 
sayuran kangkung adalah telur Ascaris lumbricoides sebanyak 3 sampel yang berada dalam bentuk infektif dan 1 telur dari spesies Trichuris trichiura.

\section{DAFTAR KEPUSTAKAAN}

Astuti R, Aminah S. 2008. Identifikasi Telur Cacing Usus pada Lalapan yang Dijual Pedagang Kaki Lima di Kawasan Simpang Lima Kota Semarang (Artikel ilmiah). Semarang : Universitas Muhammadiyah Semarang

Ferlianti, Rika. 2009. Ascaris lumbricoides dan Trichuris trichiura. [slide show]. Tersedia pada:

http://www.slideshare.net/rikaf/as caris-lumbricoides-dantrichuristrichiura?next_slideshow $=1$. Diakses pada 2 Februari 2018.

Gani, H. E, 2002. Helmintologi Kedokteran. Edisi XX. EGC. Jakarta.

Haryoto. 2009. Bertanam Kangkung Raksasa di Pekarangan. Yogyakarta: Kanisius.

Irianto, Koes. 2013. Parasitologi Medis. Bandung: Alfabeta.

Keputusan Menteri Kesehatan Republik Indonesia. 2012. Pedoman Pengedalian Kecacingan

Mutiara, Hanna. 2015. Identifikasi Kontaminasi Telur Soil Transmitted Helminth pada Makanan Berbahan Sayuran Mentah yang Dijajakan Kantin Sekitar Kampus Universitas
Lampung Bandar Lampung. Jurnal Juke Unila Vol. (5) No. 9

Natadisastra, Djaenudin., \& Ridad Agoes. 2009. Parasitologi Kedokteran. Jakarta: EGC.

Rubatzky, T., Vincen E., \& Mas Yamaguci. 1999. Sayuran Dunia 3. Bandung : ITB

Safar, Rosdiana. 2009. Protozoologi Helmintologi Entomologi. Widya Bandung: CV Yrama

Siskhawahy, 2010. Pengaruh Lama Perebusan Terhadap Keutuhan Telur Ascaris lumbricoides. Universitas Muhammadiyah Semarang. Semarang.

Zulkoni, Akhsin. 2011. Parasitologi. Yoyakarta: Nuha Medika. 